Ali M. Kutan is an associate professor of economics at Southern Illinois University, Edwardsville. Josef C. Brada is a professor of economics at Arizona State University. The authors acknowledge financial support of the National Council for Eurasian and East European Research. This paper was written while Ali M. Kutan was a visiting scholar at the Federal Reserve Bank of St. Louis. The authors thank Mike Dueker, Bill Gavin, and Chris Neely for helpful comments. Judith Hazen provided research assistance.

\section{The Evolution Of Monetary Policy In Transition Economies}

\author{
Ali M. Kutan and Josef C. Brada
}

$\mathrm{D}$ uring the past decade, a number of East and Central European countries have stabilized their economies, built up the institutions and the legal underpinnings of a market economy, and achieved sustained economic growth. In these countries, the conduct and objectives of macroeconomic policy have evolved rapidly during this time. Initially, monetary authorities used direct instruments such as credit ceilings and focused on easily understood and highly visible targets such as the nominal exchange rate. As a measure of macroeconomic stabilization was achieved, and with the emergence of the necessary markets and institutions, monetary policy has evolved toward less direct instruments such as open-market operations and toward new targets such as reducing inflation to West European levels.

In this paper, we examine the experience of three of the more successful transition economies, the Czech Republic, Hungary, and Poland. These countries' economic performances, whether measured by the level of inflation or by the resumption of economic growth after the initial shock of transition, places them at the forefront of the transition economies. They will be among the first East European countries to join the European Union (EU). Indeed, it may appear that their economies are, to a large extent, post-transition economies whose policy objectives and problems are much more like those of the advanced and middle-income market economies of Europe than those of the successor states of the former Soviet Union. Their experience in achieving this status provides valuable lessons for those transition economies that have, as yet, to develop their markets and their monetary institutions to the same extent as have these three countries.
A key policy objective for the three transition economies considered in this paper is to reduce their inflation rates to levels that prevail in the EU. To this end, they are seeking new approaches to fighting inflation, with the Czech Republic and Poland formally adopting inflation targeting as their monetary policy regime. Inflation targeting, however, like other monetary policy regimes that seek to influence prices without recourse to price controls, requires a functioning capital market to serve as a mechanism for the transmission of monetary policy. We examine the efforts to develop such markets in these countries in the next section. In the following section, we examine the evolution of monetary policy in each country, highlight the problems that monetary authorities have faced, and describe the current approach to managing inflation.

\section{CREATING A BANKING SYSTEM}

A key component of the transition in each of the three countries was to create a functioning capital market, which, in the case of the Czech Republic and Poland, required the creation of a two-tier banking system out of the former socialist state bank. The socialist banking system consisted of a state bank that not only performed the functions of a central bank, but also issued virtually all short-term credits to the country's enterprise sector. There were also several subsidiary banks with specialized functions such as financing foreign trade or servicing households' savings accounts. Credit was granted not on the basis of the creditworthiness of the firms seeking loans but rather on the need to finance activities decreed by the central plan.

\section{The Czech Republic}

In Czechoslovakia, the socialist central bank was broken up into a two-tier banking system shortly after the fall of the communist regime. The loan portfolio of the former central bank was inherited mainly by the largest of the new commercial banks, Komerční Banka, in the Czech Republic, and Všeobecná Úverová Banka in the Slovak Republic. Other commercial banks emerged from the former specialized banks (Desai, 1996, p. 469). Because of the federal structure of Czechoslovakia, most of the 
commercial banks carved out from the socialist-era central bank and from the specialized banks concentrated their activities in one Republic or the other. Thus, in 1993, when Czechoslovakia split into two independent countries, the Czech Republic and the Slovak Republic, the number of active banks in each successor country declined, and each country had to found its own central bank on the basis of the former Czechoslovak National Bank. In the Czech Republic, the Czech National Bank (CNB) was established and given the traditional functions of a central bank.

Czech commercial banks held many bad loans that had been made to state-owned firms during the socialist period. Because Komerční Banka had the biggest share of these loans, its nonperforming loan problem was the most serious, and it received the bulk of the funds that the government allocated to aiding the commercial banks. Some of the worst loans were transferred to the Consolidation Bank, which was founded precisely to manage such loans.

Privatization had a major impact on the Czech banking sector. Shares of the commercial banks were auctioned to the public through the voucher privatization, but the government remained the primary owner of each of the major banks. Perhaps more important was the fact that each commercial bank set up one or more investment privatization funds, which collected the vouchers held by citizens into a mutual fund that used these vouchers to bid for shares of companies undergoing privatization. Because about two-thirds of all available vouchers went to such investment funds, the banks became major owners of Czech industrial firms and-second only to the controlling shares held by the government - of each other. Banks have shown a proclivity to make loans to unprofitable firms in which their investment funds hold large stakes. The dominant role of the government in the ownership of the banks has raised questions about the efficiency with which bank credit is allocated by the banking system. ${ }^{1}$ As a result of these ownership ties between banks and firms, the withdrawal of banks from lending to the business sector in favor of lending to the government has been less of a problem in the Czech Republic than it was in Hungary.

The unwillingness of the Czech government to allow foreign banks to enter the market has compounded the lack of competition caused by the banks' ownership of enterprises and by the domination of the market by a few large banks. Newly founded domestic banks have been too small, subject to disadvantageous regulation and plagued by scandal. A number have failed, had their license revoked, or been taken over by the large state-owned commercial banks (Desai, 1996, pp.479-480). Although commercial banks have been required to increase their capitalization over time, aided by CNB policies that maintain high spreads between lending and borrowing rates, the financial situation of the commercial banks has not improved as much as hoped due to their continued lending to insolvent clients. Many observers believe that it will be difficult for the government to find foreign investors to take over its majority shares in Czech commercial banks.

\section{Hungary}

In Hungary, the state bank was transformed into a two-tier banking system in 1987, prior to the beginning of the transition, as part of ongoing efforts to decentralize the economy and to replace the plan with indirect state control over economic activity. The new banking system consisted of the National Bank of Hungary (NBH), which retained the functions of a traditional central bank, and five newlyorganized commercial banks. The commercial banks inherited some of the staff of the former state bank as well as the state bank's loans to state-owned firms. Three of the newly created commercial banks had country-wide sectoral mandates: Budapest Bank in industry, Magyar Hitel Bank in agriculture and Kerezkedelmi Bank in cooperatives, small businesses, and public utilities. The state-owned commercial banks started life undercapitalized, with shaky loan portfolios and with few incentives to compete with each other, to behave efficiently or even to screen against making bad loans (Bartlett, 1997, pp. 77-79; 103-108). Nevertheless, this early experience with a two-tier banking system provided important human and institutional capital for formulating and carrying out monetary policy during the subsequent transition period.

The ability of firms to service their loans from Hungarian commercial banks deteriorated at the outset of the transition because Hungarian firms suffered financial losses when their exports to the Council for Mutual Economic Assistance (CMEA) disappeared virtually overnight even as domestic

\footnotetext{
${ }^{1}$ For an analysis of Komerčni Banka's lending policies, see Snyder and Kormendi (1997). Desai (1996) provides a more general critique of the Czech banking system's performance and of the government's role as majority owner.
} 
spending collapsed. By 1991, about half the commercial banks' loans could be classified as nonperforming (Meyendorff and Snyder, 1997), and, by 1993, the two largest commercial banks were technically insolvent (Bartlett, 1997, p. 208), necessitating a series of loan consolidation programs and bank refinancings by the state.

Hungary privatized its banking sector primarily by means of sales to foreign strategic investors who assumed operating control and could inject additional funds into the banks. Bank privatization was delayed by uncertainty about the value of the banks' portfolios and their franchise value, but, by the end of 1997, the process was largely complete. The notable exceptions were Hungary's two largest commercial banks, OTP and Postabank; the latter required a major government bailout in 1998. The government's liberal policy toward the entry of foreign banks into Hungary spurred greater competition and improved the efficiency of the banking system. Nevertheless, during the transition period, Hungarian commercial banks were not effective means of channeling savings to the corporate sector. Indeed, in part because of the draconian nature of Hungarian bankruptcy laws and in part due to the need to improve their balance sheets, most commercial banks in Hungary reduced their exposure to Hungarian firms in favor of investments in government securities.

\section{Poland}

The socialist banking system in Poland was dismantled in 1989. Four state banks, specialized in foreign trade, household deposits, etc., were converted into commercial banks. Additionally, the National Bank of Poland's (NBP's) regional offices were converted into nine commercial banks, each with a network of offices and a client base that was concentrated in that region (Slay, 1996). Early on, due to lax supervision and easy-entry conditions, a number of small new banks as well as some foreignowned banks were founded. Many of these new banks succumbed either to scandal or to their inability to survive poor financial results. Subsequently, regulations regarding the founding of new banks were toughened.

The government continued as the owner of the large new commercial banks for some time. This was due to delays in implementing their privatization through a program that involved sales of stock to a combination of domestic owners and foreign strategic investors (Abarbanell and Bonin, 1997). The govern- ment also changed the structure of the industry by consolidating some commercial banks to increase their size and thus make them more competitive with foreign banks (Bonin and Leven, 1996). This was motivated by the fact that Poland, like the other two countries, soon will have to remove barriers to the entry of banks from EU countries.

Despite the regional orientation of nine of the commercial banks - which limits the extent to which they compete with each other and encourages local authorities to press these banks to lend to local firms - observers believe that Polish banks have been relatively successful in cutting ties to unprofitable firms while avoiding a major diversion of lending from corporate clients to government securities. The fact that economic growth resumed in Poland sooner and more vigorously than it did in the Czech Republic and in Hungary explains some of this more successful performance of Polish commercial banks.

\section{Summary}

All three of the transition economies have made progress in creating a banking system that corresponds to the needs of a developed market economy. Their central banks have considerable independence from government influence in following their mandates to control inflation and maintain the international value of their currency. At the same time, the commercial banking sector remains relatively fragile, plagued by poor loans made in the past as well as by questionable lending policies that, for some banks, continue to the present. These problems are most visible in the Czech Republic, but even in Poland and Hungary loan portfolios of individual commercial banks remain problematic. This weakness of the commercial bank sector, and its relatively small role in financing the investment activity of the corporate sector, limits the policies that central banks can follow and may attenuate or distort the transmission of monetary policy impulses to the economy.

The problems created by the fragility of the commercial bank sector are exacerbated by the underdevelopment of the other components of the capital market. Each of the countries has a stock exchange, but markets for shares are thin, and stock markets have performed poorly since the middle of the decade. More importantly, these stock markets provide few opportunities for raising funds through initial public offerings. Insurance companies and mortgage lending are underdeveloped or remain as monopolies of the state. The 
relative underdevelopment of the capital markets in these countries is evident when we compare the financial intermediation to gross domestic product (GDP) ratio ((bank assets + stock market capitalization + bond market capitalization) / GDP) for the three transition economies to the EU average. During 1996 this ratio was 162.4 percent for the Czech Republic, 85.9 percent for Hungary, and 63.4 percent for Poland; the corresponding figure for the EU was 288.1 percent (Fink and Haiss, 1999). Thus, even though modern banking and capital market institutions exist in these countries, they are more fragile and likely to function less effectively than the European Union countries.

\section{MACROECONOMIC POLICY IN TRANSITION}

Although the three countries differ in the starting conditions and in the details of the policies adopted, there are important similarities in their approach to stabilization and disinflation. All three began the process of transition with distorted domestic prices, unrealistic exchange rates, and open or repressed inflation. The initial objectives of macroeconomic policy were to contain the inflation that would follow from, or be intensified by, the freeing of domestic prices. To make stabilization credible, to facilitate the reorientation of trade to the West, and to underpin a liberal trade regime, nominal exchange rates were set at rates well below purchasing power parity (Halpern and Wyplosz, 1997). Policymakers expected that domestic inflation would cause real exchangerate appreciation and lead to more realistic exchange rates as these countries came closer to joining the EU.

All three countries experienced a significant decline in production at the outset (Figure 1) as a result of the collapse of CMEA trade. This placed a serious burden on fiscal policy because tax revenues declined and the need for a social safety net for the swelling numbers of unemployed increased. Monetary policy was complicated by the fact that investment in plant and equipment decreased as excess capacity emerged in many industries. Many firms failed to respond to the new environment by reducing or altering their output. Instead they accumulated large stocks of inventories and corresponding debts that threatened not only their liquidity but also that of their suppliers and of the newly created commercial banks.

\section{Figure 1}

\section{Growth of Real GDP}

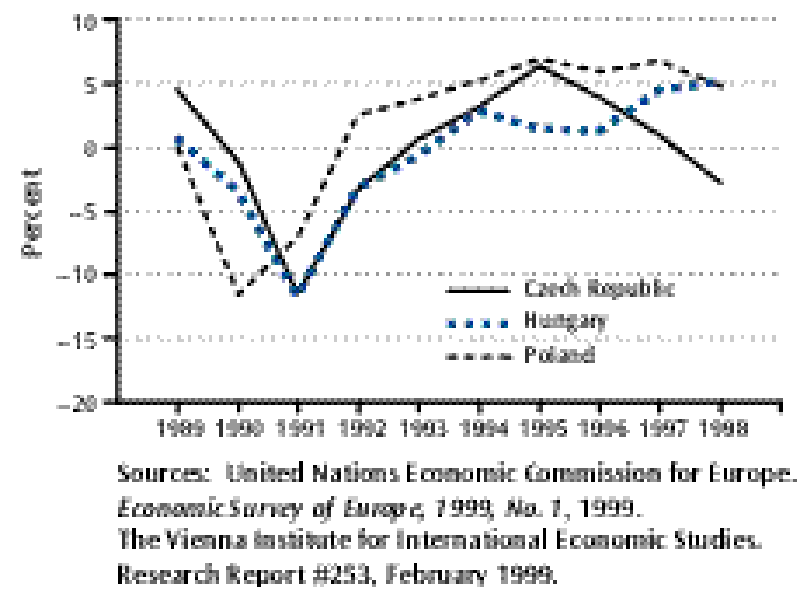

Figure 2

\section{Inflation (CPI)}

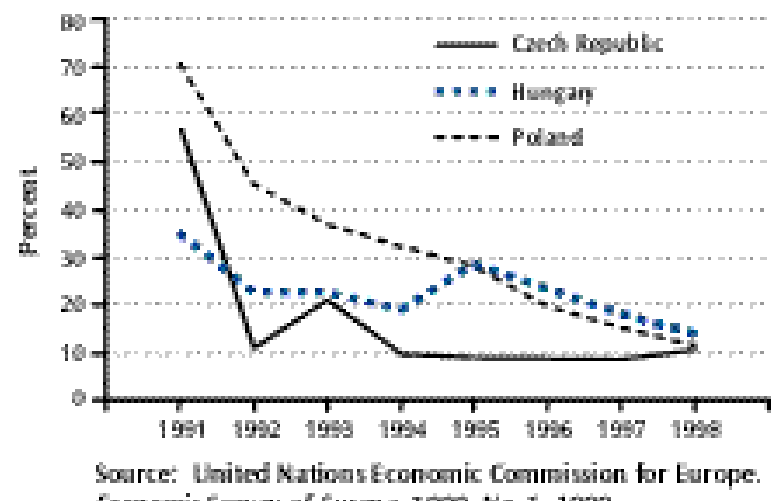

Ecanowic Sarvç of Eurque, J 1999 , Na. 1, 1999.

Over time, output recovered and inflation declined (Figure 2). Nevertheless, this decline has not brought inflation in these countries to West European levels. Thus, the current task of monetary policy is to reduce inflation in these countries with moderate levels of inflation (Cottarelli and Szapary, 1998) to low singledigit levels so that they may prepare for entry into the EU. To achieve such disinflation is crucial as it is an important prerequisite for joining the EU. Yet, tight monetary policy will hamper the ability of the firms in these countries to undertake the investments in new equipment and technology that are needed if they are to be competitive on EU markets. 


\section{Czech Republic}

The Czech Republic employed a monetary policy based on preserving the nominal exchange rate of the koruna, which was pegged from 1991 to May 1997 to a basket made up of the U.S. dollar and the Deutschmark (DM). The objective of pegging was to help fight inflation by fixing the prices of foreign goods, to make stabilization policies credible, and to attract foreign capital. The peg undervalued the koruna to allow a period of real appreciation as the domestic inflation rate outpaced that of Germany and the United States.

The Czech Republic was able to satisfy three of the four conditions proposed by Williamson (1991) for a successful exchange-rate peg. It was an open economy; it pegged to the appropriate currencies because Germany was its main trading partner, and fuel and many raw material imports were priced in U.S. dollars. Also, its external indebtedness was low and the official government budget fluctuated between surpluses and deficits that were not more than 2 percent of GDP, giving it a credible policy regime. Unfortunately, the Czech Republic did not satisfy the fourth criterion, that of achieving a rate of inflation close to those of the United States and Germany. As Figure 2 shows, the initial surge of price increases that followed market liberalization quickly subsided, but inflation persisted around 10 percent for the entire transition period. ${ }^{2}$

Fiscal policy was underutilized as a policy tool to achieve a lower inflation rate, and the fiscal surplus turned to a deficit over the years, especially if one considers off-budget expenditures and commitments. Consequently, monetary policy had to become increasingly tight to reduce the rate of inflation. At first, the CNB relied on credit refinancing quotas and other relatively direct measures to control the supply of money, although, in general, money-growth targets were overshot. Over time, more indirect measures, including changes in the reserve ratio, the short-term repo rate, and open-market operations became the key tools for controlling the money supply (Koch, 1997).

One sign of the tightening of monetary policy was the increase in nominal interest rates even as inflation declined and then held steady. In part, this suited the CNB because high interest rates not only served to deflate the economy, but also boosted commercial banks' profits, thus helping them to improve their capital positions. These high domestic interest rates, combined with an exchange-rate peg that was credible to foreigners, attracted large inflows of foreign capital. In part, such inflows were the result of borrowing by Czech firms abroad, which, of course, exposed them to danger if the koruna were ever devalued. The bulk of capital inflows consisted of short-term portfolio investments driven by the differential between Czech and West European interest rates. Because the koruna appeared to be undervalued, investors saw little danger of its devaluation and took advantage of the higher interest rates in the Czech Republic. As a result of this mismatch between the credibility of the koruna's peg and the high interest rates maintained by the CNB, short-term capital inflows began in 1993 and accelerated. By 1996, the surplus on the capital account was sufficient to more than offset a current account deficit that was in excess of 8 percent of GDP. The CNB engaged in massive, and costly, sterilization of these capital inflows.

To reduce capital inflows, on February 28, 1996, the CNB widened the intervention bands for the koruna from \pm 0.5 percent to \pm 7.5 percent. At first, this led to capital outflows and depreciation of the koruna within the widened band (jilek and Jilková, 1998), but the koruna stabilized quickly, and the CNB raised interest rates, resulting in a renewal of capital inflows and a nominal appreciation of the koruna through February of 1997. On May 13, 1997, a speculative attack on the koruna began. This attack was brought about by political uncertainty over the fate of the Klaus government, by concerns about the Czech Republic's trade deficit and the failure of exports and output to grow, and by the inability of the government to use fiscal policy to address these fundamental problems (Begg, 1997, Brada and Kutan, 1999). The CNB intervened in the foreign exchange market to defend the koruna. It expended about $\$ 2.5$ billion in reserves during this episode, and short-term interest rates rose to 50 percent. Nevertheless, by May 26, 1997, the Bank was forced to acknowledge the end of the koruna's peg. The government, rather belatedly, adopted a much more restrictive fiscal policy to stabilize the situation. The koruna initially fell by 12 percent, but, during the first half of 1998 , much of this loss was regained, due partly to improved trade performance and partly to the persistence of high interest rates.

With the abandonment of the nominal exchange rate as its target, the CNB at first proposed to follow a

\footnotetext{
2 The upsurge in inflation in 1993 was due, in large part, to the introduction of the value-added tax.
} 
policy of informally pegging to the DM, but, in December 1998, the Bank announced a policy of inflation targeting. The inflation target is set in terms of net inflation, a measure that excludes movements in regulated prices, which have been increasing quite rapidly during recent years, and the effects of indirect taxes and the elimination of subsidies. The Bank set both a "control" target of 5.5-6.5 percent for the end of 1998 and a three-year target of 3.5-5.5 percent by the end of 2000 (Czech National Bank, 1998).

\section{Hungary}

Unlike the Czech Republic, which entered the transition with a low rate of inflation, Hungarian prices rose by about 15 percent in 1987 and 1988 and by nearly 30 percent in 1989, largely because of the ongoing liberalization of the Hungarian economy. As a result of this gradual liberalization, Hungarian consumer prices better reflected supply and demand and, consequently, the effects of a further freeing of prices in 1991 led to a relatively moderate upsurge in inflation (Figure 2).

Hungary initially followed a gradualist macroeconomic policy that sought to balance the desire for reducing inflation with the need to control the government deficit and to service a large external debt. Too sharp a deflation would have reduced government revenues and increased expenditures on the social safety net, thus increasing the governments need to borrow abroad. Hungary adopted a fixed peg, with a number of small adjustments implemented during each year to account for the inflation differential between Hungary and the countries in its reference basket. ${ }^{3}$ During the early 1990s, exchangerate-policy aimed at a real appreciation of the forint to help combat domestic inflation, but, over time, this policy was seen as too costly because the declining competitiveness of Hungarian exports and sluggish growth. Moreover it failed to provide a nominal exchange-rate anchor for inflationary expectations.

These costs began to show during 1993 when the current account deficit reached 9 percent of GDP and then increased to 9.6 percent the following year. At the same time, the government's budget deficit remained unacceptably high. ${ }^{4}$ Financing this deficit required monetary expansion as well as high interest rates to attract commercial banks to government securities, thus fueling the inflation that the strong forint policy had sought to reduce. The persistence of these twin deficits created uncertainty among Hungary's foreign creditors as well as concerns about the stability of the forint.

In March of 1995, the Hungarian government adopted a major stabilization program that included a sharp reduction in government expenditures as well as tax increases. These reduced the fiscal deficit from 9.6 percent of GDP in 1994 to 7.3 percent in 1995 and 4.6 percent in $1996 .{ }^{5}$ The forint was devalued during the first two months of the year and again just prior to the introduction of the stabilization package. A crawling peg exchange-rate regime was announced. The initial rate of devaluation was 1.9 percent per month, falling to 1.3 percent for the second half of 1995 and declining further thereafter (see Szapáry and Jakab, 1998, Table 3). The devaluation of the forint, combined with the slackening of domestic demand caused by fiscal stringency, stimulated exports, and, with the help of a temporary import surcharge, reduced imports. As a result, the current account deficit as a percentage of GDP fell from 9.4 percent in 1994 to 5.6 percent in 1995 and 2.2 percent in 1997 . To slow the growth of wages and to free energy prices, the government also adopted measures to accelerate privatization. ${ }^{6}$ The rate of devaluation, preannounced in the crawling peg regime through 1998, served as a more effective nominal anchor for monetary policy than had the previous regime. It also served to reduce speculation and the timing of foreign exchange transactions to anticipate devaluation. Like the Czech Republic, Hungary sterilized some of the inflows of short-term foreign capital as interest rates rose during the poststabilization period, but in smaller amounts and at lower costs (Szapáry and Jakab, 1998, pp. 706-714).

As Figure 1 shows, economic growth slowed as the result of these measures, but it soon resumed and then accelerated. This growth has strained somewhat the macroeconomic balance, and the current account deficit increased to 4.2 percent of GDP during 1998 while the fiscal deficit rose to 4.6

\footnotetext{
${ }^{3}$ Between December 9, 1991, and May 16, 1994, the forint was pegged to a basket of 50 percent U.S. dollar and 50 percent ECU; from thereafter until March 16, 1995, it was pegged to 30 percent U.S. dollar and 70 percent ECU.

${ }^{4}$ The government deficit, including privatization receipts in revenue, was 6.7 percent in 1993 and 9.6 percent in 1994 on an accrual basis.

${ }^{5}$ For the background on the discussions leading up to the design and adoption of the stabilization program, see Kornai (1997, Chs. 2-6)

${ }^{6}$ Real wages fell by 12.0 percent during 1995 along with a further 5 percent decrease during 1996
} 
percent of GDP. Inflation has declined steadily, in part due to falling prices of imports and also because of the forint's slowing rate of depreciation.

\section{Poland}

The stabilization of the Polish economy began under much less favorable conditions than those found in the Czech Republic and Hungary. During 1989 , inflation peaked at 54.8 percent per month, the government deficit was nearly 8 percent of GDP, and both loss-making Polish firms and the government deficit were financed by the rapid expansion of money and credit. Although the government began to deal with the crisis in late 1989 , major stabilization began on January 1,1990, with the introduction of the so-called Balcerowicz Plan. This plan had several components. The zloty (zl) was devalued from 5,560 $\mathrm{zl} / \$$ to $9,500 \mathrm{zl} / \$$ and pegged at the latter rate. Monetary and fiscal policies were tightened, enabling the government to achieve a surplus equivalent to 0.4 percent of GDP, and credit creation was sharply curtailed. ${ }^{7}$ The popiwek, a punitive tax on above-average wage increases, was enacted to slow the growth of wages.

The consequences of this, the first stabilization and liberalization effort in a transition economy, were sufficiently virulent - both in the upsurge in prices and in the decline of production - to lead to an easing of macroeconomic policy late in 1990. The effects of this policy change, however, were felt more in an acceleration of inflation than in real output growth (Wellisz, 1997), and the government soon abandoned this effort. As the recession deepened during 1991, the fiscal deficit reappeared and high inflation (see Figure 2) reduced the competitiveness of Polish exports. The zloty was devalued by 16.8 percent, and its peg was shifted to a basket of currencies.

Policy priorities gradually shifted from stabilization to stimulating growth (Krzak, 1996). Although the fiscal deficit was cut from 6 percent of GDP in 1992 to 2.8 percent in 1993, a level around which it has fluctuated since, monetary policy was relatively expansionary. While interest rates remained positive, money supply and credit growth consistently outpaced targets set by the NBP. The zloty's peg was abandoned in October of 1991, replaced by a crawling peg with a preannounced devaluation of 1.8 percent per month against a basket of currencies. Over time, the rate of depreciation has been reduced, and there also have been one-off devaluations and revaluations to accommodate exogenous shocks. ${ }^{8}$ During 1995, the band within which the zloty could fluctuate was widened to \pm 7 percent. Poland's exchange rate policy was sufficiently credible to foreign investors that short-term capital inflows began to be a problem for the NBP by 1995, when, even with some NBP sterilization, capital inflows accounted for 59 percent of the growth of the money supply (Krzak, 1996, p. 57).

Although Poland has had the highest rate of inflation of the three countries throughout the 1990s, it also has had the fastest growth of aggregate output. This may be due as much to its earlier start in implementing economic reforms as to better economic policy; just as its higher rate of inflation may better reflect its prestabilization situation rather than a poorer ability to restrain the growth of the money supply than displayed by the other two countries considered in this paper. Recently, this output growth has slowed somewhat because of a fall in exports to Russia and the Ukraine which is due to the financial crises in those countries. Because inflation has slackened and because the nominal anchor of the crawling peg has decreased in importance with a further widening of the bands, Poland, like the Czech Republic, has adopted inflation targeting as the framework for its monetary policy. During 1998, the Monetary Policy Council set a goal of lowering Polish inflation to 6.8-7.8 percent in 1999 and 4 percent as measured by the CPI, by the year 2003 .

\section{Lessons and Their Implications for Monetary Policy}

All three countries have stabilized inflation at moderate levels and, except for the recent recession in the Czech Republic, succeeded in generating sustained growth. Although different initial conditions and the different starting times of stabilization programs resulted in somewhat different paths, the trajectories of their growth and inflation have converged. Indeed, by the second half of 1998 , inflation seemed to be falling toward single-digit levels in the three countries. In the Czech Republic, the monthly year-on-year rate of inflation as measured by the CPI fell to 6.8 percent in December 1998. In Hungary, the comparable figure was 10.5 percent, and in Poland it was 8.6 percent. These harbingers of the end of double-digit inflation were accurate only for the

\footnotetext{
${ }^{7}$ One reason for the fiscal turnaround was that inflation caused firms to overestimate their profits due to a failure to account properly for the effects of inflation on inventories

${ }^{8}$ See Koch (1997) for details.
} 
Czech Republic where, during the first half of 1999 , the CPI grew between 1 and 2 percent on a monthon-month basis. In Hungary, inflation accelerated and exceeded 10 percent by summer's end. Polish CPI growth increased on a month-on-month basis, raising doubts about whether the NBP's inflation targets for the year will be achieved.

Whether the three countries can continue with the process of disinflation and achieve West European rates of CPI growth during the next few years depends on three factors. The first and most important of these is whether they can continue to support monetary policy with the appropriate fiscal policy. The instances in which fiscal policy was tightened in these three countries-Poland in 1993, the Czech Republic in 1997, and Hungary in 1995-amply demonstrate the effectiveness of fiscal policy in influencing both the domestic economy and exports and imports. Also evident in all three countries is a tendency for passive fiscal policy to lead to gradually larger fiscal deficits. The second factor influencing the course of inflation in the region is the international environment. All three countries benefited greatly from the fall in the prices of imports, particularly those of fuels and raw materials. Agricultural prices have also been stable due to good harvests and cheap imports from the EU. During early 1998, all three countries also benefited from the general strength, if not the actual appreciation, of their currencies. This trend reversed itself during late 1998 as oil prices began to increase and as the currencies of all three countries weakened, setting the stage for higher import prices to feed through to the domestic price level.

The third factor influencing the course of inflation in the Czech Republic and Poland is whether a new approach to monetary policy based on inflation targeting will be effective. The belief of both the CNB and the NBP is that, if inflation targeting can be made credible, then much of the persistence of past inflation on inflationary expectations will be reduced as central bank credibility is strengthened and as inflationary expectations become more forward looking rather than backward looking.

The success of inflation targeting in the Czech Republic and Poland depends on whether the central banks of these countries have the policy autonomy to carry out a policy of inflation targeting and whether the institutional and policy environment is conducive to doing so. To begin with, it is unclear what either the CNB or the NBP mean by inflation targeting. For example, McDonough (1997) argues that inflation targeting means that the central bank has only one objective, the future price level, to the exclusion of other nominal and real targets such as employment or the level of aggregate output. This may be something of an extreme view, as Masson et al. (1997) take inflation targeting to mean that the central bank has inflation as the "explicit goal" (p. 6) and that this goal "takes precedence over all other objectives" (p.9). Dittmar et al. (1999) take a seemingly even more permissive view, claiming that inflation targeting means that the "...central bank...focuses on inflation but also cares about...employment, output growth...." The issue of what the central banks mean by inflation targeting is not academic, because Dittmar et al. show that the consequences of including additional goals can be quite costly in terms of the variability of inflation, especially when measured over longer periods. Neither the CNB nor the NBP have made much of an effort to indicate precisely what they mean by inflation targeting. Such lack of clarity may provide the banks with a measure of flexibility in setting goals and objectives, but it does little to make the process of setting monetary policy more credible or transparent. Thus, the lack of clarity may defeat a primary purpose of having an inflation target, that is, helping people form more accurate expectations of inflation.

Inflation targeting is viewed as having important advantages over other forms of monetary policy. First, it provides a nominal anchor, the price level, for monetary policy. Second, inflation targeting implies a transparent policy target, one that both the public and the government can understand and observe. This leads to the third advantage, namely that the central bank's accountability is increased, and to the extent that the bank meets its goals, its credibility is increased as well.

Masson et al. (1997), however, argue that there are important prerequisites that must be met if inflation targeting is to be lead to low and stable inflation. The first of these is central bank independence. De jure, the operational independence of the CNB and the NBP is on a par with that of the industrialized countries that use inflation targeting. This is less so, however, in the case of goals to be pursued. For example, the CNB was criticized widely for maintaining high interest rates during 1998, perhaps as the result of a backward-looking approach to interest rate determination, but such criticism of tactics need not be seen as an infringement on the CNB's independence. More troubling is that during 1998, as the Czech economy slid into recession, the 
leaders of the two major parties met with the governor of the CNB and criticized him for the Bank's failure to pay sufficient attention to employment and output in its policy decisions. In Poland, the Bank is concerned not only about the inflation target, but also the nominal exchange rate. This is due largely to considerations surrounding Poland's prospective entry into the EU.

A second prerequisite is that there be no fiscal dominance, meaning that the central bank's policy not be dictated by the need to finance the fiscal deficit of the government. Again, de jure, both countries have safeguards against the central bank being forced to finance the government. Nevertheless, in realityand especially if we consider the banking system as a whole - this becomes a troublesome issue. In Poland, the seignorage to GDP ratio has been relatively high by international standards. In the Czech Republic, commercial banks do not receive interest on required reserves, another form of revenue for the government. As mentioned above, the commercial banking sector in both countries has tended to have a healthy appetite for government debt at the expense of lending to the business sector. Thus the de jure ability of the central banks to avoid having to finance the government may be subverted by the commercial banks' evident willingness to do so.

Finally, central banks following an inflationtargeting policy should avoid other nominal targets. In the case of Poland, the intervention bands for the zloty are quite wide, but, as mentioned above, the zloty's exchange rate continues to be pegged to the U.S. dollar and to the Euro. The Czech Republic's koruna officially floats, but it is quite possible that the CNB maintains an informal peg to the DM and intervenes in the market to support this unstated peg. Thus, both central banks may well face conflicts between alternative nominal goals in the future.

It is too early to pass judgment on the effectiveness of inflation targeting in the two countries. During the first half of 1999 , inflation in the Czech Republic was below the target range, largely due to the recession from which the country is recovering very slowly. In Poland the inflation during mid-1999 was at or above the upper limit of the NBP's forecast. These potential failures to achieve inflation goals do not mean that inflation targeting cannot be a workable policy regime in the longer term. Nevertheless, there is a danger that either undershooting and overshooting inflation targets may convince the population that their central banks have little impact on the rate of inflation, thus undermining policy credibility.

\section{CONCLUSIONS}

The Czech Republic, Hungary and Poland have made considerable progress in stabilizing and liberalizing their economies. Monetary policy has made a significant contribution to stabilization and there has been a remarkable development in these countries' financial institutions and markets. Nevertheless, the relative newness and fragility of these markets and institutions is of concern because of the heavy burden placed on monetary authorities battling to reduce inflation. It will be important to continue to strengthen the capital market in these countries and to provide more active fiscal policy support for monetary policy.

\section{REFERENCES}

Abarbanell, Jeffery S., and John P. Bonin. "Bank Privatization in Poland: The Case of Bank Slaski," Journal of Comparative Economics (August 1997), pp. 31-61.

Bartlett, David L. The Political Economy of Dual Transformations: Market Reform and Democratization in Hungary, University of Michigan Press, 1997.

Begg, David. "Monetary Policy During Transition: Progress and Pitfalls in Central and Eastern Europe, 1990-6," Oxford Review of Economic Policy, Special Issue: Economics of Transition in Eastern and Central Europe (Summer 1997), pp. 33-46.

Bonin, John P., and Bozena Leven. "Polish Bank Consolidation and Foreign Competition: Creating a Market-Oriented Banking Sector," Journal of Comparative Economics (August 1996), pp. 52-72.

Brada, Josef C., and Ali M. Kutan. "The Persistence of Moderate Inflation in the Czech Republic," Post-Soviet Geography and Economics (March 1999), pp. 121-34.

Cottarelli, Carlo, and György Szapáry, eds. Moderate Inflation: The Experience of Transition Economies, Washington: International Monetary Fund and National Bank of Hungary, 1998

Czech National Bank, Inflation Report, July 1998.

Desai, Raj M. "Reformed Banks and Corporate Governance in the Czech Republic, 1991-1996," Post-Soviet Geography and Economics (October 1996), pp. 463-94.

Dittmar, Robert, William T. Gavin, and Finn E. Kydland. "Price-Level Uncertainty and Inflation Targeting," this Review (July/August 1999), pp. 23-33.

Fink, Gerhard, and Peter R. Haiss. "Central European Financial Markets from an EU Perspective," Paper presented at the Meetings of the Allied Social Sciences Association, New York, 1999. 


\section{REVIEW}

Halpern, László, and Charles Wyplosz. "Equilibrium Exchange Rates in Transition Economies," International Monetary Fund Staff Papers (December 1997), pp. 430-61.

Jílek, Josef, and Jirina Jilková. “The Reaction of Residents and Nonresidents to the Widening of the Intervention Band of the Czech Koruna," Eastern European Economics (January-February 1998), pp. 66-81.

Koch, Elmar B. Exchange Rates and Monetary Policy in Central Europe - A Survey of Some Policy Issues. Oesterreichische Nationalbank Working Paper 24, September 1997.

Kornai, János. Struggle and Hope: Essays on Stabilization and Reform in a Post-Socialist Economy, Edward Elgar, 1997.

Krzak, Maciej. "Persistent Moderate Inflation in Poland and Hungary," Focus on Transition 2/1996, Vienna: Oesterreichische Nationalbank, 1996.

Masson, Paul R., Miguel A. Savastano, and Sunil Sharma. "The Scope for Inflation Targeting in Developing Countries," International Monetary Fund Working Paper WP/97/130, October 1997.

McDonough, William J. "A Framework for the Pursuit of Price Stability," Federal Reserve Bank of New York Economic Policy Review (August 1997), pp. 1-7.

Meyendorff, Anna, and Edward A. Snyder. "Transactional Structures of Bank Privatizations in Central Europe and Russia," Journal of Comparative Economics (August 1997), pp. 5-30.

Slay, Ben. "Polish Banks on the Road to Recovery," PostSoviet Geography and Economics (October 1996), pp. 511-22.

Snyder, Edward A., and Roger C. Kormendi. "Privatization and Performance of the Czech Republic's Komerční Banka," Journal of Comparative Economics (August 1997), pp. 97-128.

Szapáry, György, and Zoltán M. Jakab. "Exchange Rate Policy in Transition Economies: The Case of Hungary," Journal of Comparative Economics (December 1998), pp. 691-717.

Wellisz, Stanislaw. "Inflation and Stabilization in Poland, 1990-95," in Macroeconomic Stabilization in Transition Economies, Mario I. Blejer and Marko Skreb, eds., Cambridge University Press, 1997.

Williamson, John. "Advice on the Choice of an Exchange Rate Policy," in Exchange Rate Policies in Developing and Post-Socialist Countries, E. M. Claassen, ed., ICS Press, 1991, pp. 395-403. 